\title{
Pengaruh Lingkungan Kerja dan Kompensasi Terhadap Kinerja Melalui Motivasi Karyawan Bagian Produksi UD.Lumintu Ambulu Jember
}

\author{
The Influence of The Work Environment and Compensation On Performance \\ Through Motivation of The Production Employees UD. Lumintu Ambulu \\ Jember
}

\author{
Elok Faiqotul Jannah, Diana Sulianti K. Tobing ${ }^{1}$, Sunardi \\ Jurusan Manajemen, Fakultas Ekonomi, Universitas Jember \\ Jln. Kalimantan 37, Jember 68121 \\ dskltse@yahoo.com
}

\begin{abstract}
Abstrak
Penelitian ini bertujuan untuk mengetahui dan menganalisis pengaruh lingkungan kerja dan kompensasi terhadap kinerja melalui motivasi karyawan bagian produksi UD.Lumintu Ambulu Jember. Bentuk penelitian ini adalah explanatory research. Sampel penelitian ini adalah 35 responden. Populasi dalam penelitian ini bertindak pula sebagai sampel sehingga penelitian ini termasuk ke dalam penelitian populasi (sensus). Hasil penelitian ini menunjukkan bahwa lingkungan kerja dan kompensasi berpengaruh secara langsung maupun tidak langsung terhadap kinerja melalui motivasi karyawan bagian produksi UD.Lumintu Ambulu Jember.
\end{abstract}

Kata Kunci: Kinerja, kompensasi, lingkungan kerja, motivasi

\begin{abstract}
This research aims to know and analyze the influence of the work environment and compensation on performance through motivation of the production employees UD.Lumintu Ambulu Jember. This research perform with explanatory research. The sample was 35 respondents. The population in this study as well as samples so this research included in the population research (census). These results indicate that the work environment and compensation effect directly or indirectly to the performance through motivation of the production employees UD.Lumintu Ambulu Jember.
\end{abstract}

Keywords: Compensation, motivation, performance, work environment

\section{Pendahuluan}

Industri di Indonesia semakin berkembang seiring dengan tuntutan kebutuhan berbagai macam produk. Hal tersebut menyebabkan persaingan di dunia usaha semakin ketat sehingga menuntut perusahaan untuk lebih meningkatkan kualitas sumber daya manusia yang mereka miliki. Oleh karena itu diperlukan sumber daya manusia yang berkualitas yang mampu melaksanakan tugasnya dengan baik agar masalah-masalah yang timbul dalam perusahaan dapat teratasi. Pada umumnya setiap perusahaan tentu menginginkan para karyawannya untuk memiliki kinerja yang baik. Robbins (2001:187) mengatakan bahwa kinerja karyawan merupakan fungsi interaksi antara kemampuan (ability), motivasi (motivation), dan kesempatan (opportunity). Kinerja adalah hasil kerja secara kualitas dan kuantitas yang dicapai seorang karyawan dalam melaksanakan tugasnya sesuai tanggung jawab yang diberikan kepadanya (Mangkunegara, 2009:67). Kinerja karyawan dipengaruhi oleh beberapa faktor diantaranya lingkungan kerja, kompensasi, dan motivasi. Lingkungan kerja yang nyaman dan kompensasi yang cukup akan mampu meningkatkan motivasi kerja karyawan yang nantinya akan berpengaruh pada peningkatan kinerja karyawan.

UD.Lumintu Ambulu Jember adalah usaha dagang yang bergerak di bidang mebel (furniture). Proses produksi mebel UD.Lumintu meliputi beberapa tahap yaitu proses penggergajian kayu, penyiapan komponen, perakitan, dan proses akhir (finishing) pengamplasan dan pengepakan. Proses produksi tersebut berpotensi menimbulkan polusi udara di tempat kerja yang berupa debu kayu. Debu kayu tersebut akan mencemari udara dan lingkungan sehingga karyawan bagian produkse-Journal Ekonomi Bisnis dan Akuntansi akan terpapar debu. Selain itu, penggunaan alatalat pertukangan seperti mesin serut listrik, gergaji, gurinda dan bor juga akan mengeluarkan suara yang bising sehingga akan memicu timbulnya gangguan pendengaran. Keadaan

1 Coresponding Author 
lingkungan kerja seperti itu akan mengganggu kesehatan dan kenyamanan karyawan dalam bekerja dan berkomunikasi. Dalam kondisi lingkungan kerja yang kurang nyaman tersebut, perusahaan perlu mempertahankan karyawannya dengan memberikan solusi dan kompensasi yang baik agar karyawan termotivasi untuk lebih giat bekerja dan meningkatkan kinerjanya.

\section{Metode}

\section{Rancangan atau Desain Penelitian}

Berdasarkan latar belakang masalah dan rumusan masalah yang ada, karakteristik masalah yang diteliti dalam penelitian ini diklasifikasikan sebagai penelitian penjelasan (explanatory research) yaitu metode penelitian untuk meneliti ada tidaknya pola hubungan dua variabel atau lebih.

\section{Jenis dan Sumber Data}

Jenis data yang digunakan dalam penelitian ini meliputi data primer dan data sekunder. Data primer diperoleh dari wawancara dan penyebaran kuesioner. Data sekunder dalam penelitian ini diperoleh melalui buku bacaan yang terkait dengan variabel yang diteliti, data yang diperoleh dari internet, dan jurnal-jurnal yang berkaitan.

\section{Populasi dan Sampel}

Populasi dalam penelitian ini adalah seluruh karyawan bagian produksi UD.Lumintu Ambulu Jember yang berjumlah 35 orang. Populasi dalam penelitian ini bertindak pula sebagai sampel sehingga penelitian ini termasuk ke dalam penelitian populasi (sensus).

\section{Metode Analisis Data}

Alat analisis yang digunakan dalam penelitian ini adalah analisis jalur (path analysis).

\section{Hasil Dan Pembahasan}

\section{Uji Instrumen}

Uji instrumen dalam penelitian ini meliputi uji validitas, uji reliabilitas dan uji normalitas data. Uji validitas dalam penelitian ini menggunakan product moment pearson's dengan angka kritis taraf signifikan 5\%. Dari pengujian yang telah dilakukan diketahui bahwa masing-masing indikator memiliki nilai product moment pearson's dengan signifikasi $0,000-0,048<0,05$, sehingga indikator dalam penelitian ini dinyatakan relevan atau valid.

Uji reliabilitas dalam penelitian ini menggunakan metode Cronbach Alpha. Dari pengujian yang telah dilakukan diketahui bahwa data yang diperoleh bersifat reliabel atau layak sebagai alat dalam pengumpulan data.

Uji normalitas data dalam penelitian ini mengunakan kolmogorov-smirnov test dengan menetapkan derajat keyakinan $(\alpha)$ sebesar 5\%. Dari pengujian yang telah dilakukan diketahui bahwa nilai probabilitas untuk masingmasing variabel lebih besar dari 0,05 , sehingga dapat dinyatakan bahwa data dalam penelitian berdistribusi normal.

\section{Uji Asumsi Klasik}

Uji asumsi klasik dalam penelitian ini meliputi uji normalitas model, uji multikolinieritas dan uji heteroskedastisitas. Dari uji normalitas model yang dilakukan, diketahui bahwa data dalam penelitian ini berdistribusi normal sehingga dapat dinyatakan bahwa model regresi dalam penelitian ini rnemenuhi asumsi normalitas.

Dari uji multikolinieritas diketahui bahwa tidak terjadi multikolinearitas antar variabel independent karena pengujian menunjukkan nilai VIF kurang dari 10.

Uji heteroskedastisitas menunjukkan bahwa tebaran data tidak membentuk garis tertentu atau tidak terdapat pola yang jelas, serta titik-titik menyebar diatas dan dibawah angka nol pada sumbu Y, sehingga tidak ada heteroskedastisitas dalam penelitian ini.

\section{Analisis Jalur}

Analisis jalur berkaitan dengan studi ketergantungan suatu variabel dependen pada satu atau lebih variabel independen atau intervening dengan tujuan untuk mengetahui seberapa besar pengaruh variabel independen atau intervening terhadap variabel dependen. Berikut pada Tabel 1 disajikan hasil analisis jalur:

Tabel 1. Hasil Analisis Jalur

\begin{tabular}{cccccc}
\hline Jalur & Beta $(\beta)$ & Sig. & & $a$ & $\begin{array}{c}\text { Keteran } \\
\text { gan }\end{array}$ \\
\hline $\mathrm{X}_{1} \rightarrow \mathrm{Z}$ & 0,441 & 0,006 & $<$ & 0,05 & $\begin{array}{c}\text { Signifi } \\
\text { kan }\end{array}$ \\
$\mathrm{X}_{2} \rightarrow \mathrm{Z}$ & 0,356 & 0,024 & $<$ & 0,05 & $\begin{array}{c}\text { Signifi } \\
\text { kan }\end{array}$ \\
$\mathrm{X}_{1} \rightarrow \mathrm{Y}$ & 0,348 & 0,016 & $<$ & 0,05 & $\begin{array}{c}\text { Signifi } \\
\text { kan }\end{array}$ \\
$\mathrm{X}_{2} \rightarrow \mathrm{Y}$ & 0,510 & 0,001 & $<$ & 0,05 & $\begin{array}{c}\text { Signifi } \\
\text { kan }\end{array}$ \\
$\mathrm{Z} \rightarrow \mathrm{Y}$ & 0,690 & 0,001 & $<$ & 0,05 & $\begin{array}{c}\text { Signifi } \\
\text { kan }\end{array}$ \\
$\alpha 1$ & 0,603 & - & & - & - \\
$\alpha 2$ & 0,056 & - & & - & - \\
$\varepsilon 1$ & 0,547 & - & & - & - \\
$\varepsilon 2$ & 0,493 & - & & - & - \\
\hline
\end{tabular}

Sumber : data diolah, 2015

Berdasarkan hasil analisis jalur diperoleh hasil yang dapat dinyatakan berikut:

a. Pengaruh lingkungan kerja terhadap motivasi

Variabel lingkungan kerja terhadap motivasi diperoleh nilai signifikasi $0,006<0,05$. Maka Ho ditolak dan Ha diterima, yang berarti ada pengaruh lingkungan kerja terhadap motivasi. Nilai positif berarti jika ada peningkatan pada variabel lingkungan kerja akan meningkatkan motivasi; 


\section{b. Pengaruh kompensasi terhadap motivasi}

Variabel kompensasi terhadap motivasi diperoleh nilai signifikasi $0,024<0,05$. Maka Ho ditolak dan Ha diterima, yang berarti ada pengaruh kompensasi terhadap motivasi. Nilai positif berarti jika ada peningkatan pada variabel kompensasi akan meningkatkan motivasi;

\section{c. Pengaruh lingkungan kerja terhadap kinerja karyawan}

Variabel lingkungan kerja terhadap kinerja karyawan diperoleh nilai signifikasi $0,016<0,05$. Maka Ho ditolak dan Ha diterima, yang berarti ada pengaruh lingkungan kerja terhadap kinerja karyawan. Nilai positif berarti jika ada peningkatan pada variabel lingkungan kerja akan meningkatkan kinerja karyawan;

\section{d. Pengaruh kompensasi terhadap kinerja karyawan}

Variabel kompensasi terhadap kinerja karyawan diperoleh nilai signifikasi $0,001<0,05$. Maka Ho ditolak dan Ha diterima, yang berarti ada pengaruh kompensasi terhadap kinerja karyawan. Nilai positif berarti jika ada peningkatan pada variabel kompensasi akan meningkatkan kinerja karyawan;

\section{e. Pengaruh motivasi terhadap kinerja karyawan}

Variabel motivasi terhadap kinerja karyawan diperoleh signifikasi $0,001<0,05$. Maka Ho ditolak dan Ha diterima, yang berarti ada pengaruh motivasi terhadap kinerja karyawan. Nilai positif berarti jika ada peningkatan pada variabel motivasi akan meningkatkan kinerja karyawan;

f. Pengaruh $\varepsilon 1$ variabel lain selain $X_{1}$, dan $X_{2}$ terhadap $Z$

$$
\begin{aligned}
\varepsilon 1 & =\sqrt{ } 1-\mathrm{R} \\
& =\sqrt{ } 1-0,700 \\
& =\sqrt{ } 0,3 \\
& =0,547 \text { atau } 54,7 \%
\end{aligned}
$$

artinya keragaman data yang dapat dijelaskan oleh variabel selain $X_{1}$, dan $X_{2}$ dalam model tersebut adalah sebesar 54,7 \%. g. Pengaruh $\varepsilon 2$ variabel lain selain $\mathrm{X}_{1}$ dan $\mathrm{X}_{2}$ terhadap $\mathrm{Y}$

$$
\begin{aligned}
\varepsilon 2 & =\sqrt{ } 1-\mathrm{R}^{2} \\
& =\sqrt{ } 1-0,756 \\
& =\sqrt{ } 0,224 \\
& =0,493 \text { atau } 49,3 \%
\end{aligned}
$$

artinya keragaman data yang dapat dijelaskan oleh variabel selain $X_{1}$ dan $X_{2}$ dalam model tersebut adalah sebesar 49,3\%.

\section{h. Koefisien determinasi total $\left(\mathrm{R}_{\mathrm{m}}^{2}\right)$}

Dalam teori trimming pengujian validitas model riset diamati melalui perhitungan koefesien determinasi total sebagai berikut :

$$
\begin{aligned}
\mathrm{R}_{\mathrm{m}}^{2}=1-(\mathrm{P} \varepsilon 1)^{2}(\mathrm{P} \varepsilon 2)^{2} \\
\quad=1-(0,547)^{2}(0,493)^{2} \\
=1-0,073 \\
=0,927
\end{aligned}
$$

artinya keragaman data yang dapat dijelaskan oleh model atau persamaan tersebut adalah sebesar $92,7 \%$ atau dengan kata lain informasi yang terkandung di dalam data $92,7 \%$ dapat dijelaskan oleh model tersebut, sedangkan 0,73\% dijelaskan oleh variabel lain (yang belum terdapat di dalam model) dan error.

\section{Hasil Perhitungan Jalur}

a. Pengaruh langsung (Direct Effect)

1) Pengaruh langsung variabel lingkungan kerja terhadap motivasi adalah sebesar $44,1 \%$;

2) Pengaruh langsung variabel kompensasi terhadap motivasi adalah sebesar $35,6 \%$;

3) Pengaruh langsung variabel lingkungan kerja terhadap kinerja karyawan adalah sebesar $34,8 \%$;

4) Pengaruh langsung variabel kompensasi terhadap kinerja karyawan adalah sebesar $51 \%$;

5) Pengaruh langsung variabel motivasi terhadap kinerja karyawan adalah sebesar $69 \%$.

b. Pengaruh tidak langsung (Indirect Effect)

1) Pengaruh secara tidak langsung variabel lingkungan kerja melalui motivasi kerja terhadap kinerja karyawan $(0,441.0,690)=0,304$ atau $30,4 \%$.

2) Pengaruh secara tidak langsung variabel kompensasi melalui motivasi kerja terhadap kinerja karyawan $(0,356.0,690)=0,245$ atau $24,5 \%$

\section{3) Total Effect}

(a) Total Effect : $\mathrm{Y} \leftarrow \mathrm{X}_{1} \rightarrow \mathrm{Z} \rightarrow \mathrm{Y}, 0,348+0,304=0,652$ atau $65,2 \%$;

(b) Total Effect : $\mathrm{Y} \leftarrow \mathrm{X}_{2} \rightarrow \mathrm{Z} \rightarrow \mathrm{Y}, 0,510+0,245=0,755$ atau $75,5 \%$;

\section{Pembahasan}

Hasil pengujian koefisien dari analisis jalur, menunjukkan bahwa lingkungan kerja dan kompensasi berpengaruh langsung terhadap kinerja karyawan bagian produksi UD.Lumintu Ambulu Jember dan berpengaruh secara tidak langsung terhadap kinerja melalui motivasi karyawan bagian produksi UD.Lumintu Ambulu Jember. Berdasarkan hasil pengujian tersebut, maka dapat disimpulkan bahwa hipotesis yang menyatakan, ada pengaruh lingkungan kerja dan kompensasi terhadap kinerja karyawan bagian produksi UD.Lumintu Ambulu Jember adalah diterima.

\section{Pengaruh Lingkungan Kerja Terhadap Motivasi}

Hasil penelitian menunjukkan bahwa lingkungan kerja terhadap motivasi terbukti berpengaruh signifikan. Hal ini sesuai dengan hipotesis pertama yang menyatakan bahwa lingkungan kerja berpengaruh signifikan terhadap motivasi karyawan bagian produksi UD.Lumintu Ambulu Jember. Ditunjukkan berdasarkan hasil pengujian yang memiliki nilai signifikasi $0,006<0,05$ sehingga $\mathrm{H} 0$ ditolak. Sedangkan besarnya nilai koefisen regresi sebesar 0,441 mengindikasikan pengaruh lingkungan kerja terhadap motivasi adalah positif. Artinya semakin baik lingkungan 
kerja akan mendorong tingginya motivasi karyawan. Hasil penelitian ini sejalan dengan yang telah dilakukan oleh Lezita (2010) yang menunjukkan bahwa terdapat hubungan yang signifikan antara faktor-faktor lingkungan kerja dengan motivasi kerja karyawan PT. Sinar Sosro Kantor Penjualan Bogor.

Menurut Nitisemito (2000:183) lingkungan kerja adalah segala sesuatu yang ada disekitar pekerja dan yang mempengaruhi dirinya dalam menjalankan tugas-tugas yang dibebankan. Untuk dapat meningkatkan motivasi karyawan maka diperlukan adanya suatu kondisi sekitar lingkungan kerja yang nyaman, aman, bergairah dan sikap saling terbuka antar pegawai didalamnya. Karena dengan motivasi kerja yang tinggi karyawan dapat melaksanakan tugas yang dibebankan kepadanya dengan baik sehingga berdampak pada sikap percaya pada perusahaan.

Variabel lingkungan kerja merupakan variabel yang memiliki pengaruh dominan paling kuat terhadap tingkat motivasi karyawan dibandingkan dengan variabel independen lainnya. UD.Lumintu menyediakan ruangan yang luas dan memadai yang terdiri dari ruang terbuka dan ruang tertutup. UD.Lumintu menempatkan alat-alat berbahaya seperti gergaji dan alat-alat tajam lainnya di tempat yang aman, menyediakan masker untuk melindungi karyawan dari debu kayu dan menyediakan peralatan kerja yang layak pakai serta memadai bagi karyawannya dalam melakukan aktivitas pertukangan. Fasilitas yang disediakan oleh UD.Lumintu tersebut memberikan rasa aman kepada karyawan dalam bekerja. Selain itu, hubungan antar karyawan dan hubungan antara karyawan dengan atasan terjalin dengan baik sehingga karyawan merasa nyaman dan dihargai.

\section{Pengaruh Kompensasi Terhadap Motivasi}

Hasil penelitian menunjukkan kompensasi mempunyai pengaruh yang signifikan terhadap motivasi. Hal ini sesuai dengan hipotesis kedua yang menyatakan bahwa kompensasi berpengaruh signifikan terhadap motivasi karyawan bagian produksi UD.Lumintu Ambulu Jember. Ditunjukkan berdasarkan hasil pengujian yang memiliki nilai signifikasi $0,024<0,05$ sehingga H0 ditolak. Sedangkan besarnya nilai koefisen regresi pengaruh kompensasi terhadap motivasi sebesar 0,356. mengindikasikan pengaruh kompensasi terhadap motivasi adalah positif. Artinya semakin baik kompensasi yang diberikan akan mendorong tingginya motivasi karyawan. Hasil penelitian ini sejalan dengan yang telah dilakukan oleh Ramadhani (2013) yang menunjukkan bahwa kompensasi berpengaruh signifikan terhadap motivasi kerja karyawan di PT. Pos Indonesia (Persero) Bandung.

Menurut Hasibuan (2008:121) salah satu tujuan pemberian balas jasa (kompensasi) adalah untuk memberikan motivasi. Cara memotivasi karyawan adalah dengan memenuhi apa yang mereka butuhkan. Salah satu kebutuhannya adalah kompensasi yang diterima dari perusahaan. Jika kompensasi yang diberikan sesuai dengan harapan karyawan maka pimpinan akan mudah memotivasi karyawan untuk dapat mencapai tujuan perusahaan.

UD.Lumintu memberikan upah kepada karyawannya sesuai dengan beban dan pengorbanan yang telah dilakukan.
Karyawan mengatakan upah yang diterima sudah sesuai dengan harapan dan selalu diberikan tepat waktu. Karyawan dari UD.Lumintu akan berkerja ekstra karena upah dan bonus yang diberikan telah dirasa sesuai. UD.Lumintu menyediakan THR dan Jamsostek, serta menyediakan berbagai fasilitas dalam memberikan kenyamanan pada karyawannya. Kompensasi tersebut akan menciptakan adanya rasa gembira pada karyawannya, serta dapat meningkatkan semangat didalam berkerja sehingga karyawan akan termotivasi untuk bekerja.

\section{Pengaruh Lingkungan Kerja Terhadap Kinerja}

Hasil penelitian menunjukkan bahwa lingkungan kerja terhadap kinerja terbukti berpengaruh signifikan. Hal ini sesuai dengan adanya asumsi yang diajukan pada hipotesis ketiga yang menyatakan lingkungan kerja berpengaruh signifikan terhadap kinerja karyawan bagian produksi UD.Lumintu Ambulu Jember. Ditunjukkan berdasarkan hasil pengujian yang memiliki nilai signifikasi $0,016<0,05$ sehingga H0 ditolak. Sedangkan besarnya nilai koefisen regresi pengaruh lingkungan kerja terhadap kinerja sebesar 0,348 mengindikasikan pengaruh lingkungan kerja terhadap kinerja adalah positif. Artinya semakin baik lingkungan kerja akan meningkatkan kinerja karyawan. Besarnya nilai koefisien pengaruh tidak langsung lingkungan kerja terhadap kinerja melalui motivasi sebesar 0,304 , sedangkan pengaruh totalnya sebesar 0,652 . Nilai pengaruh langsung lebih besar dari nilai pengaruh tidak langsung sehingga keberadaan motivasi sebagai mediasi kurang berperan. Hasil penelitian yang menunjukkan lingkungan kerja berpengaruh signifikan baik langsung maupun tidak langsung terhadap kinerja sejalan dengan penelitian yang dilakukan oleh Merysca (2013) yang menunjukkan bahwa lingkungan kerja berpengaruh signifikan terhadap kinerja karyawan melalui motivasi kerja pada PT. Bank CIMB Niaga Tbk. Cabang Jember.

Sukanto dan Indrijo (1999:151) menyatakan bahwa lingkungan kerja yang buruk akan mempengaruhi pekerja, kinerja menjadi menurun, karena pekerja merasa terganggu dalam pekerjaannya, sehingga tidak dapat mencurahkan perhatian penuh terhadap pekerjaannya. Lingkungan kerja yang nyaman dan menyenangkan membuat karyawan tidak merasa bosan sehingga dengan suasana hati yang senang akan memicu karyawan untuk melakukan pekerjaannya dengan baik.

\section{Pengaruh Kompensasi Terhadap Kinerja}

Hasil penelitian menunjukkan kompensasi mempunyai pengaruh yang signifikan terhadap kinerja. Hal ini sesuai dengan hipotesis keempat yang menyatakan kompensasi berpengaruh signifikan terhadap kinerja karyawan bagian produksi UD.Lumintu Ambulu Jember. Ditunjukkan berdasarkan hasil pengujian yang memiliki nilai signifikasi $0,001<0,05$ sehingga H0 ditolak. Sedangkan besarnya nilai koefisen regresi pengaruh kompensasi terhadap kinerja sebesar 0,510, mengindikasikan pengaruh kompensasi terhadap kinerja adalah positif. Artinya semakin baik kompensasi yang diberikan akan meningkatkan kinerja karyawan. Besarnya nilai koefisien pengaruh tidak langsung kompensasi terhadap kinerja melalui motivasi sebesar 0,245, 
sedangkan pengaruh totalnya sebesar 0,755 . Nilai koefisien pengaruh langsung lebih besar dari pengaruh tidak langsung sehingga keberadaan variabel mediasi kurang berperan. Namun nilai total pengaruh kompensasi terhadap kinerja melalui motivasi merupakan nilai terbesar sehingga kompensasi memberikan kontribusi yang besar terhadap peningkatan kinerja karyawan. Hasil penelitian yang menunjukkan kompensasi berpengaruh signifikan baik langsung maupun tidak langsung terhadap kinerja sejalan dengan penelitian Dito (2010) yang menunjukkan bahwa kompensasi berpengaruh tidak langsung terhadap kinerja melalui motivasi kerja karyawan PT. Slamet Langgeng Purbalingga.

Hasibuan (2008:121) mengatakan bahwa salah satu tujuan pemberian kompensasi adalah motivasi. Jika balas jasa yang diberikan cukup besar, pimpinan akan mudah memotivasi bawahannya. Menurut Robbins (2007:213) motivasi merupakan proses yang berperan pada intensitas, arah, dan lamanya berlangsung upaya individu ke arah pencapaian sasaran. Sehingga apabila seorang karyawan menganggap bahwa kompensasi yang diberikan oleh perusahaan sesuai dengan yang karyawan harapkan, maka akan dapat memotivasi karyawan untuk meningkatkan kinerja karyawan.

\section{Pengaruh Motivasi Terhadap Kinerja}

Hasil penelitian menunjukkan motivasi mempunyai pengaruh yang signifikan terhadap kinerja karyawan. Hal ini sesuai dengan hipotesis kelima yang menyatakan bahwa motivasi kerja berpengaruh signifikan terhadap kinerja karyawan bagian produksi UD.Lumintu Ambulu Jember. Ditunjukkan berdasarkan hasil pengujian yang memiliki nilai signifikansi sebesar $0,001<0,05$ sehingga H0 ditolak. Sedangkan besarnya nilai koefisen regresi pengaruh motivasi kerja terhadap kinerja karyawan sebesar 0,690. Hasil penelitian ini sejalan dengan yang telah dilakukan oleh Prasetyo (tanpa tahun) pada karyawan produksi CV. Jaya Abadi Furniture Jepara yang menunjukkan motivasi mempunyai pengaruh terhadap kinerja karyawan dengan arah positif, artinya apabila motivasi semakin baik maka kinerja karyawan akan meningkat.

Hasibuan (2008:92) menyatakan motivasi itu penting karena dengan motivasi diharapkan setiap karyawan mau bekerja dan antusias untuk mencapai kinerja yang tinggi. Pemberian motivasi yang tepat pada karyawan akan memberikan dorongan untuk berbuat semaksimal mungkin dalam melaksanakan tugasnya karena dengan keberhasilan organisasi mencapai tujuan dan berbagai sasarannya , kepentingan-kepentingan pribadi para anggota organisasi tersebut akan terpelihara juga. Dapat diketahui bahwa motivasi dapat mendorong manusia untuk bekerja dengan semangat, penuh kegairahan dan lebih giat lagi sehingga diharapkan dapat meningkatkan kinerjanya di perusahaan.

\section{Simpulan}

Berdasarkan hasil analisis yang telah dilakukan pada penelitian ini, maka dapat ditarik kesimpulan bahwa lingkungan kerja dan kompensasi berpengaruh positif dan signifikan terhadap motivasi kerja karyawan bagian produksi UD.Lumintu Ambulu Jember; lingkungan kerja dan kompensasi berpengaruh positif dan signifikan terhadap kinerja karyawan bagian produksi UD.Lumintu Ambulu Jember baik secara langsung maupun tidak langsung melalui motivasi; serta motivasi kerja berpengaruh positif dan signifikan terhadap kinerja karyawan bagian produksi UD.Lumintu Ambulu Jember.

\section{Referensi}

Dito, Anoki Herdian. 2010. "Pengaruh Kompensasi Terhadap Kinerja Karyawan PT. Slamet Langgeng Purbalingga dengan Motivasi Kerja Sebagai Variabel Intervening". Skripsi. Semarang : Universitas Diponegoro. Robbins,

Hasibuan, Malayu S.P. 2008. Organisasi dan Motivasi. Jakarta: PT.Bumi Aksara.

Lezita. 2010. "Pengaruh Lingkungan Kerja Terhadap Motivasi Kerja Karyawan Pada PT. Sinar Sosro Kantor Penjualan Bogor". Skripsi. Bogor : Institut Pertanian Bogor.Stephen P. 2007. Perilaku Organisasi. PT Indeks.

Mangkunegara, A.A. Anwar Prabu. 2009. Evaluasi Kinerja SDM. Cetakan Keempat. Bandung : Refika Aditama

Merysca, Devynda Ayu. 2013. "Analisis Pengaruh Lingkungan Kerja, Kompensasi dan Program Pengembangan Terhadap Kinerja Karyawan Melalui Motivasi Kerja Pada PT. Bank CIMB Niaga Tbk. Cabang Jember". Tidak dipublikasikan. Skripsi. Jember : Fakultas Ekonomi Universitas Jember.

Nitisemito, Alexs. 2000. Manajemen Suatu Dasar dan Pengantar. Jakarta: Ghalia Indonesia

Prasetyo, Rony. (Tanpa Tahun). "Pengaruh Motivasi Kerja, Kepemimpinan, dan Lingkungan Kerja Terhadap Kinerja Karyawan (Studi Kasus Pada Karyawan Produksi Cv. Jaya Abadi Furniture Jepara)”. Jurnal. Semarang : Universitas Dian Nuswantoro Semarang.

Ramadhani, Ayu Anisa. 2013. "Pengaruh Kompensasi Terhadap Motivasi Kerja Karyawan Di PT. Pos Indonesia (Persero) Bandung. Skripsi. Bandung: Universitas Pendidikan Indonesia. 